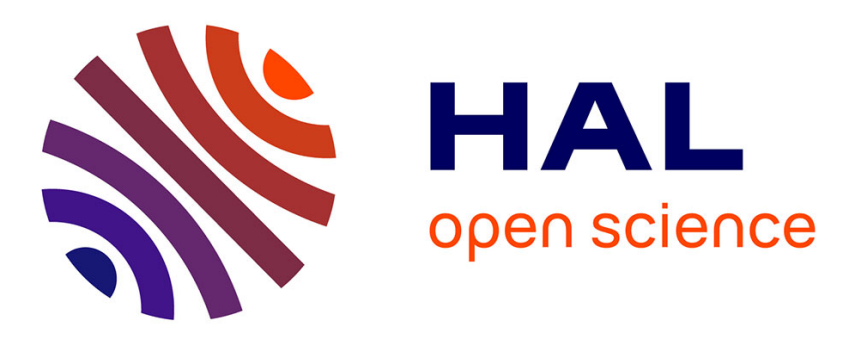

\title{
Synthesis of alkyl esters by cutinase in miniemulsion and organic solvent media
}

\author{
Dragana P.C. de Barros, Luís Fonseca, Joaquim M. S. Cabral, Clemens K \\ Weiss, Katharina Landfester
}

\section{- To cite this version:}

Dragana P.C. de Barros, Luís Fonseca, Joaquim M. S. Cabral, Clemens K Weiss, Katharina Landfester. Synthesis of alkyl esters by cutinase in miniemulsion and organic solvent media. Biotechnology Journal, 2009, 4 (6), pp.674-n/a. 10.1002/biot.200800294 . hal-00480830

\section{HAL Id: hal-00480830 https://hal.science/hal-00480830}

Submitted on 5 May 2010

HAL is a multi-disciplinary open access archive for the deposit and dissemination of scientific research documents, whether they are published or not. The documents may come from teaching and research institutions in France or abroad, or from public or private research centers.
L'archive ouverte pluridisciplinaire HAL, est destinée au dépôt et à la diffusion de documents scientifiques de niveau recherche, publiés ou non, émanant des établissements d'enseignement et de recherche français ou étrangers, des laboratoires publics ou privés. 


\section{Synthesis of alkyl esters by cutinase in miniemulsion and organic solvent media}

\begin{tabular}{|r|l|}
\hline Journal: & Biotechnology Journal \\
\hline Manuscript ID: & BIOT-2008-0294.R1 \\
\hline Wiley - Manuscript type: & Research Article \\
\hline Date Submitted by the & 05-Feb-2009 \\
\hline Complete List of Authors: & $\begin{array}{l}\text { de Barros, Dragana P.C.; Instituto Superior Técnico, Institute for } \\
\text { Biotechnology and Bioengineering, Centre for Biological and } \\
\text { Chemical Engineering } \\
\text { Fonseca, Luís; Instituto Superior Técnico, Institute for } \\
\text { Biotechnology and Bioengineering, Centre for Biological and } \\
\text { Chemical Engineering } \\
\text { Cabral, Joaquim M. S.; Instituto Superior Técnico, Institute for } \\
\text { Biotechnology and Bioengineering, Centre for Biological and } \\
\text { Chemical Engineering } \\
\text { Weiss, Clemens; Max-Plank-Institute for Polymer Research } \\
\text { Landfester, Katharina; Max-Plank-Institute for Polymer Research }\end{array}$ \\
\hline Keywords: & \begin{tabular}{l} 
alkyl esters, miniemulsion, organic solvent, cutinase \\
\hline
\end{tabular} \\
\hline
\end{tabular}

\section{S) ScholaroNE \\ Manuscript Central}


$\underline{\text { Research Article }}$

Synthesis of alkyl esters by cutinase in miniemulsion and organic solvent media

$\underline{\text { Dragana P. C. de Barros }}^{1}$, Luís P.Fonseca ${ }^{1}$, Joaquim M.S.Cabral ${ }^{1}$, Clemens K. Weiss ${ }^{2}$, Katharina Landfester ${ }^{2}$,

1 Institute for Biotechnology and Bioengineering, Instituto Superior Técnico, Centre for Biological and Chemical Engineering, 1049-001 Lisbon, Portugal

${ }^{2}$ Max-Planck-Institute for Polymer Research, Ackermannweg 10, 55128 Mainz, Germany

Keywords: alkyl esters, miniemulsion, organic solvent, cutinase

Dragana P.C. de Barros

Instituto Superior Técnico,

IBB-Institute for Biotechnology and Bioengineering,

Centre for Biological and Chemical Engineering

Av. Rovisco Pais , 1049-001, Lisbon, Portugal

dragana@ist.utl.pt

phon: +351218419065

fax: +351218419062 


\begin{abstract}
The main objective of this work was to study and test the nature and influence of reaction media (organic solvent $v s$. miniemulsion system) on the synthesis of alkyl esters catalyzed by Fusarium solani pisi cutinase. Ester synthesis and cutinase selectivity for different chain length of acids and alcohols (ethyl and hexyl) were evaluated.

In iso-octane cutinase exhibits rates of esterification after one hour between 0.24 $\mu$ molmg ${ }^{-1} \min ^{-1}$ for ethyl oleate and $1.15 \mu \mathrm{molmg}^{-1} \mathrm{~min}^{-1}$ for ethyl butyrate, while in miniemulsion system were from $0.05 \mu \mathrm{molmg}^{-1} \mathrm{~min}^{-1}$ for ethyl heptanoate to $0.76 \mu \mathrm{molmg}^{-1} \mathrm{~min}^{-1}$ for ethyl decanoate. The reaction rate for the synthesis of hexyl esters in miniemulsion system was from $0.19 \mu \mathrm{molmg}^{-1} \mathrm{~min}^{-1}$ for hexyl heptanoate to $1.07 \mu \mathrm{molmg}^{-1} \mathrm{~min}^{-1}$ for hexyl decanoate.

High conversion yields of $95 \%$ at equilibrium after $8 \mathrm{~h}$ of reaction in iso-octane for pentanoic acid $\left(\mathrm{C}_{5}\right)$ with ethanol at equimolar concentration $(0.1 \mathrm{M})$ was achieved.

Additionally, this work also shows that a significant and unexpected change in cutinase selectivity occurred for longer chain length carboxylic acids $\left(\mathrm{C}_{8}-\mathrm{C}_{10}\right)$ in miniemulsion system comparing with organic solvent (iso-octane) and previous studies in reverse micellar systems where a selectivity towards short chain fatty acids $\left(\mathrm{C}_{4}-\mathrm{C}_{6}\right)$ was observed. The possibility to work with higher concentration of substrates, without inhibitiory effect on enzyme, was another advantage of miniemulsion system.
\end{abstract}




\section{Introduction}

Alkyl esters belong to the group of flavor compounds that are very important parts of aromas, applied in food, beverage, cosmetic and pharmaceutical industries. The esters of short chain acids $\left(\mathrm{C}_{6}-\mathrm{C}_{10}\right)$ and alcohols $\left(\mathrm{C}_{2}-\mathrm{C}_{6}\right)$ are well-known flavor and fragrance compounds. These compounds have odors of different fruits and are parts of complex mixtures providing specific aromas. Longer chain acids esters $\left(\mathrm{C}_{18}\right)$ are used in cosmetic industry as emollient for personal care applications [1].

Enzymatic synthesis of flavor esters is an interesting and innovative process for aroma production for current and future industrial applications.

Until now the aroma esters were generally produced via the chemical catalytic or by extraction from natural sources. The products chemically synthesized are characterized by low purity and they are not classified as natural products. On the other hand natural aromas obtained by the extraction are very expensive and their quality very often depends on climate and geographic conditions.

Specificity and selectivity of biocatalysts are providing the possibility of working at mild reaction conditions, without undesirable side reactions, generating the product with high degree of purity. As a further benefit the products are no racemic mixtures but usually only one stereoisomer. These are the main advantages of using enzymes in new industrial flavor manufacture processes [2-4]. Moreover, the increasing sensitivity today for environmentally friendly process 
and preference for "green" technology and "natural" products favor the synthesis of flavor compounds via biotechnology route [5-6].

Lipases are mostly used as biocatalyst for the reactions of hydrolysis, esterification and transesterification. Lipases are characterized by their catalytic action preferably at the interface between water and an insoluble substrates or organic solvent containing the reactatns. Another interesting group of hydrolytic enzymes are cutinases, also which belong to the class of serine esterase as most of the lipases do [7-8] but in comparison to the lipase they are not characterized by the phenomenon of interfacial activation.

Industrially, lipases were first used in hydrolytic processes in aqueous media, but increasing interest focuses on their potential use as biocatalysts for new processes in various reaction media due to their great importance and role for esterification reactions. Thus, the esterification reactions were performed in non-conventional media such as organic solvents (biphasic systems, reverse micellar, and monophasic system) [7], supercritical fluids [9], ionic liquids [10], aqueous twophase systems [11], or solid-gaseous media [12]. There are several advantages in using organic solvent as reaction media such as increased solubility of nonpolar substrates and products, shifting thermodynamic equilibrium to favor the ester synthesis in relation to hydrolysis, and the minimization of enzyme inhibition by substrates or products, etc. Still, there are disadvantages of using organic media, which can lead to denaturation or inhibition of the enzyme, separation of solvent from the product, lack of green solvent, and their compatibility with the demands and regulations of FDA and other official regulatory agencies [5]. Supercritical 
fluids have been used in reaction of enzymatic synthesis regarding their physical properties [13-14]. Recently, ionic liquids have been explored as alternative for organic solvent, but this investigation still has to be approved in future [15-16]. As in esterification reactions two products, ester and water are generated, the influence and accumulation of water in the reaction medium has significant influence on the chemical equilibrium. For successful high-yield esterification the water has to be removed from the site of the reaction. Different techniques were used for water removal to shift the equilibrium from reactants to products [17-18]. Irrespective of the limiting aspect of water in esterification reactions, successful efforts have been put in using water as a (green) reaction medium for enzyme transformations [19-20].

Miniemulsions are heterophase systems consisting of uniform, small droplets in a continuous phase characterized by high stability. They are obtained using intensive shearing force. A typical miniemulsion system used for an esterification reaction is composed of an oil phase (as substrates) containing a hydrophobic agent (e.g. hexadecane), an emulsifier (usually non-ionic surfactant) stabilizing the oil reactant droplets, and water. The mixture is homogenized by high shear (e.g. ultrasonification) to obtain homogenous and monodisperse droplets in the size range of about $200 \mathrm{~nm}$ dispersed in water [21-22]. Esterification is performed by the addition of an enzyme as a biocatalyst dissolved in the aqueous phase Fig 1 . Lipase catalyzed esterification is well established [28] and was shown to be highly efficient in the production of long chain phenylalkanoates at mild reaction conditions.. 
The objectives of the presented studies are to investigate and compare the conditions of the enzymatic synthesis of flavor esters by Fusarium solani pisi cutinase produced by Sacharomyces cerevisiae SU50 in two different media: first, organic media, in particular iso-octane, an organic solvent recognized as safe ingredient in food and beverage industrial processes by FDA, and second in miniemulsion system allowing to use water as reaction medium for ester synthesis.

\section{MATERIALS AND METHODS}

\subsection{Materials}

Cutinase from Fusarium solani pisi was produced as described previously [23-24] and used for enzymatic esterification. Reagents including acetic (96\%, ACROS, Belgium), butyric (99.5\%, FLUKA, Germany), pentanoic (99.5\%, FLUKA, Germany), hexanoic (98\%, FLUKA, Germany), heptanoic, octanoic (99\%, SIGMA, Germany), decanoic and oleic acid (FLUKA, Germany), and ethanol abs. (Merck, Germany) and hexanol (Merck, Germany) were used for ester synthesis while hexadecane 99\% (SIGMA, Germany) and LutensolAT-50 powder (donation from BASF, Germany) were used to obtain miniemulsion system. All other chemicals used were analytical grade. $\mathrm{NaOH}$ (Merck, Germany) as reagent and tetrahydrofuran (THF) (Merck, Germany) as solvent for titration were used.

Iso-octane (Sigma-Aldrich, Germany) was used in the reaction medium and ndecane (VWR, Germany) was used as internal standard for Gas Chromatography (GC) analysis. Anhydrous sodium sulfate, in powder form (Sigma-Aldrich, 
Germany), was used to dry samples from organic solvent after esterification and before GC analysis.

\subsection{Production of cutinase}

The $F$. solani pisi cutinase wild-type was produced by recombinant $S$. cerevisiae SU50 strain. The cutinase producing S. cerevisiae SU50 strain (Mata, leu2-3, ura3, gall:URA3, ML-S, MAL3, SUC3) contains the expression vector pUR7320 constructed and provided by the Unilever Research Laboratory, Vlaardingen, the Netherlands. The strain was stored at $-80^{\circ} \mathrm{C}$ in frozen tubes containing selective medium and 50\% (v/v) glycerol (Merck, Germany) [23].

\subsection{Purification of cutinase and production of lyophilized enzyme preparation}

The isolation and purification of cutinase excreted by recombinant $S$. cerevisiae SU50 strain was carried out by expanded bed adsorption (EBA) [24]. Frontal adsorption experiments were carried out in an EBA column Streamline 25 with a settled bed adsorbent height of $15 \mathrm{~cm}$ and the column top adjusted to $45 \mathrm{~cm}$. The cation adsorbent Streamline SP XL from Amersham Pharmacia Biotech, Sweden was used to isolate the cutinase directly from the fermentation broth. The cutinase activity and protein concentration of the collected effluent fractions from the column were determined after each run. The pool of elution fractions exhibiting highest cutinase activity were previously dialyzed against $20 \mathrm{mM}$ phosphate buffer pH 7.0 and then frozen at $-80^{\circ} \mathrm{C}$ and lyophilized (B. Braun Biotech. International 
CHRIST Alpha 2-4) overnight. Lyophilized pure cutinase was stored deep-frozen at $-20^{\circ} \mathrm{C}$ before used in esterification reactions.

\subsection{Characterization of the cutinase preparations}

The cutinase estereolytic activity and protein content were assayed and lyophilized cutinase preparations characterized [25-27].

The protein concentration was determined by the method of PEARCE (BCA assay). Protein concentrations were determined with reference to a standard, the Bovine Serum Albumin (BSA) (Merck) [25].

The cutinase estereolytic activity was assayed using a spectrophotometric method, based on monitoring the hydrolysis of p-nitrophenylbutyrate (p-NPB) to nitrophenol (p-NP), a yellow compound easily identify and quantify by the absorbance at $400 \mathrm{~nm}$. An aliquot $(20 \mu \mathrm{l})$ was added to a reaction mixture composed of $980 \mu \mathrm{l}$ of a solution in $50 \mathrm{mM}$ potassium phosphate buffer $\mathrm{pH}=7.0$ also containing $0.56 \mathrm{mM}$-NPB, $11.3 \mathrm{mM}$ sodium cholate and $0.43 \mathrm{M}$ tetrahydrofuran.

One unit of cutinase estereolytic activity was defined as the amount of enzyme required to convert $1 \mu \mathrm{mol}$ of $\mathrm{p}$-NPB to $\mathrm{p}$-NP per $1 \mathrm{~min}$, under controlled adjusted condition. The extinction coefficient of $\mathrm{p}-\mathrm{NP}$ was considered to be $1.84 \times 10^{4}\left(\mathrm{M}^{-}\right.$ ${ }^{1} \mathrm{~cm}^{-1}$ ), as indicated by the supplier (Sigma) [26]. 


\subsubsection{Determination of esterification degree in miniemulsion system}

Analysis of reaction mixture was determined by liquid 1H NMR spectroscopy (Bruker $400 \mathrm{MHz}$ ) using DMSO-d 6 (Deutero GmbH, Germany) as solvent. 
The esterification yield has been calculated from the ratio of the area of the methylene protons adjacent to the carboxyl-group $\left({ }^{\alpha}{ }^{\prime} \mathrm{CH}_{2}\right)$ at $2.26 \mathrm{ppm}$ to the sum of the areas of ester $\left({ }^{\alpha \prime} \mathrm{CH} 2\right)$ at $2.26 \mathrm{ppm}$ and acid protons $\left({ }^{2} \mathrm{CH}_{2}\right)$ at $2.18 \mathrm{ppm}$ defined as in Eq. (1). The sum of ester and acid concentrations was equal to the initial acid concentration.

Eq. (1):

$\%$ esterification $=\frac{\left[\mathrm{RCOOR}^{\prime}\right]}{[\mathrm{RCOOH}]_{0}}=\frac{[\text { integration area of ester }]}{[\text { integration area of ester }]+[\text { integration area of acid }]}$

An example for ${ }^{1} \mathrm{H}$ NMR spectra for synthesis of ethyl decanoate is shown in Fig.

2.

Titration of free acids in reaction media (Schott Titronic, Germany) was used as control method for monitoring the progress of esterification. At given incubation periods, aliquots of $100 \mu \mathrm{l}$ of the reaction mixture were withdrawn using a syringe and were immediately diluted in $300 \mu \mathrm{THF}$ in order to stop the enzyme action. The degree of esterification was monitored by determination of residual acid content by titration against sodium hydroxide $(0.1 \mathrm{M} \quad \mathrm{NaOH})$ using phenolphthalein as an indicator.

\subsection{Esterification catalyzed by lyophilized cutinase in iso-octane}

The esterification of acid and alcohol at equimolar concentration $(0.1 \mathrm{M})$ catalyzed by cutinase was also carried out in iso-octane, as reaction medium because it was observed that the enzyme is inhibited by substrate concentrations higher than 


\subsubsection{Monitoring and determination of esterification degree in iso-octane}

The concentration of ethanol, carboxylic acids (acetic acid, pentanoic acid, hexanoic acid, octanoic acid, decanoic acid, oleic acid) and ethyl esters (ethyl acetate, ethyl pentanoate, ethyl hexanoate, ethyl octanoate, ethyl decanoate, ethyl oleate) was determined by a Hewllet-Packard model 5890 gas chromatography 
(GC) equipped with a flame ionization detector (FID). The WCOT Fused Silica coating CP Chirasil- Dex CB column, $25 \mathrm{~m}$ x $0.25 \mathrm{~mm}, \mathrm{DF}=0.25$ (Varian Inc.) was used. N-decane was used as the internal standard and to calculate ethyl esters and respective substrates concentrations in the reaction media based on the results of GC analysis according the following specific conditions applied for each particular ethyl ester and respective substrates:

Ethyl acetate: oven temperature was held at $50^{\circ} \mathrm{C}$ for $4 \mathrm{~min}$ before being elevated to $150^{\circ} \mathrm{C}$ for $3.67 \mathrm{~min}$ at $30^{\circ} \mathrm{C} / \mathrm{min}$; injector temperature was set at $200{ }^{\circ} \mathrm{C}$; detector temperature was set at $250^{\circ} \mathrm{C}$; carrier gas was nitrogen.

Ethyl butyrate: oven temperature was held at $50^{\circ} \mathrm{C}$ for $4 \mathrm{~min}$ before being elevated to $150^{\circ} \mathrm{C}$ for $2.34 \mathrm{~min}$ at $15^{\circ} \mathrm{C} / \mathrm{min}$; injector temperature was set at 200 ${ }^{\circ} \mathrm{C}$; detector temperature was set at $250{ }^{\circ} \mathrm{C}$; carrier gas was nitrogen.

Ethyl pentanoate: oven temperature was held at $50^{\circ} \mathrm{C}$ for $4 \mathrm{~min}$ before being elevated to $170^{\circ} \mathrm{C}$ for $2 \mathrm{~min}$ at $30^{\circ} \mathrm{C} / \mathrm{min}$; injector temperature was set at $200{ }^{\circ} \mathrm{C}$ and detector temperature is set at $250^{\circ} \mathrm{C}$; carrier gas was nitrogen.

Ethyl hexanoate: oven temperature was held at $50^{\circ} \mathrm{C}$ for $4 \mathrm{~min}$ before being elevated to $160^{\circ} \mathrm{C}$ for $1.67 \mathrm{~min}$ at $15^{\circ} \mathrm{C} / \mathrm{min}$; injector temperature was set at 200 ${ }^{\circ} \mathrm{C}$; detector temperature was set at $250^{\circ} \mathrm{C}$; carrier gas was nitrogen.

Ethyl octanoate: oven temperature was held at $50^{\circ} \mathrm{C}$ for 4 min before being elevated to $180^{\circ} \mathrm{C}$ for $3.67 \mathrm{~min}$ at $30^{\circ} \mathrm{C} / \mathrm{min}$; injector temperature was set at 200 ${ }^{\circ} \mathrm{C}$; detector temperature was set at $250^{\circ} \mathrm{C}$; carrier gas was nitrogen. 
Ethyl decanoate: oven temperature was held at $50^{\circ} \mathrm{C}$ for 4 min before being elevated to $190^{\circ} \mathrm{C}$ for $4.34 \mathrm{~min}$ at $30^{\circ} \mathrm{C} / \mathrm{min}$; injector temperature was set at 200 ${ }^{\circ} \mathrm{C}$; detector temperature was set at $250^{\circ} \mathrm{C}$; carrier gas was nitrogen.

Ethyl oleate: oven temperature was held at $50^{\circ} \mathrm{C}$ for $4 \mathrm{~min}$ before being elevated to $190^{\circ} \mathrm{C}$ for $5.34 \mathrm{~min}$ at $30^{\circ} \mathrm{C} / \mathrm{min}$; injector temperature was set at $200{ }^{\circ} \mathrm{C}$; detector temperature was set at $250{ }^{\circ} \mathrm{C}$; carrier gas was nitrogen.

\section{RESULTS AND DISCUSION}

3.1. Influence of chain length of acids and alcohols on enzymatic esterification

\subsubsection{Esterification in miniemulsion system}

This studies on the synthesis of alkyl esters using cutinase were based on previous work carried out by Aschenbrenner et al. [28]. The authors successfully established a miniemulsion system for the synthesis of monoesters of linear carboxylic acids with $\omega$-phenyl alkanoles using various lipases ( Chirazyme L-5 from Candida antartica, Lipase G from Penicilium cammemberti, Lipase PS from

Pseudomonas cepacia). As this system has shown to yield high conversions in very short reactions times at mild conditions, the range of substrates was extended to linear alcohols. Various carboxylic acids including hexanoic $\left(\mathrm{C}_{6}\right)$, heptanoic $\left(\mathrm{C}_{7}\right)$, octanoic $\left(\mathrm{C}_{8}\right)$, decanoic $\left(\mathrm{C}_{10}\right)$ and oleic acid $\left(\mathrm{C}_{18}\right)$, and two short chain alcohols ethanol $\left(\mathrm{C}_{2}\right)$ and hexanol $\left(\mathrm{C}_{6}\right)$ were used for enzymatic esterification. With other acids with chain length lower than $\mathrm{C}_{6}$ it was not possible to obtain 
stable miniemulsion systems, while hexanoic acid $\left(\mathrm{C}_{6}\right)$ is the shortest acid that allows to obtain a miniemulsion system. Nevertheless the system is rather unstable as few minutes after addition of the enzyme and start of the esterification reaction, phase separation occurred and the reaction stopped. The water solubility of the short chain acids is too high, so the acid will diffuse from the droplet into the aqueous phase. This observation is consistent with the results obtained by Aschenbrenner et al., who also observed phase separation in systems with acid substrates shorter than seven C-atoms.

This is probably due to the fact that acids with lower chain lengths can act as cosurfactants at the oil/water interface and lower the interfacial tension so that the droplet size decreases or do not allow the formation of stable emulsion droplets, in spite of using a concentration of Lutensol of $1.62 \%(\mathrm{w} / \mathrm{w})$, the surfactant in the present miniemulsion system (Table 2). Additionally, these short acids are also characterized by low viscosity and hydrophobicity that allows diffusion from the emulsion droplets into the water phase [29].

The acids with longer chain length than $\mathrm{C}_{6}$ and the two alcohols tested in the miniemulsion systems have different solubility in water and, consequently, different capacity to be encapsulated into the emulsion droplets. Ethanol is completely miscible with water, whereas hexanol is only slightly soluble in water $\left(590 \mathrm{mg} / 100 \mathrm{~g}\right.$ at $\left.25^{\circ} \mathrm{C}\right)$ [33] while the solubility of the acids decreases with increasing chain length (Table 3). According to these values of solubility it is possible to conclude that almost all of the acids and hexanol were located inside 
the emulsion droplets while ethanol can be found in the water phase as well as in the droplets (Table 3 ).

Furthermore cutinase presented an extraordinary synthetic capacity in the miniemulsion system with optimized composition (Table 2) which was carried out previously by other enzyme [28].

The main goal of this work was thus to explore the esterification potential of cutinase for these types of substrates ( as named previously), and to assess the possibility to work with high substrates concentrations ( Table 1). The influence of different concentration of substrates on reaction rate and mass transport phenomena will be studied and published in following work.

The conversion rates of ester synthesis by cutinase in miniemulsion show a direct relationship to increasing acid chain length with a maximum for decanoic acid $\left(\mathrm{C}_{10}\right)$. This could be observed for both alcohols applied (ethyl esters and hexyl esters) with rates of 0.76 and $1.07 \mu$ molmg ${ }^{-1} \mathrm{~min}^{-1}$ for ethanol and hexanol, respectively obtained in the first hour of reaction (Fig 3).

These results show an interesting and unexpected shift of cutinase specificity to higher chain length of acids $\left(\mathrm{C}_{10}\right)$ when compared with results obtained for reactions of esterification and transesterification performed in reverse micellar system. Here the short chain acids $\left(\mathrm{C}_{4}-\mathrm{C}_{6}\right)$ were esterified with higher specificity [30-32]. On other hand, cutinase showed higher esterification reaction specificity for hexanol than ethanol confirming the results obtained already in reverse micellar systems [30-32] The only exception was found for ethyl oleate and hexyl oleate where rate of ester synthesis was almost equal $\left(0.33\right.$ and $0.29 \mu \mathrm{molmg}^{-1}$ 
$\min ^{-1}$ for ethyl and hexyl esters respectively). Thus, it is possible to conclude that miniemulsion system forms a different microenvironment for the enzyme that changes slightly the cutinase specificity in favor of the longer chain of acids $\left(\mathrm{C}_{8^{-}}\right.$ $\mathrm{C}_{10}$ ) and not for specific type of alcohol.

The esterification reactions in miniemulsion system were monitored during $24 \mathrm{~h}$ showing that the equilibrium was definitively achieved for all esters after $8 \mathrm{~h}$. The specific time, for which maximum conversion could be detected, depends on the chain length of acid and alcohol. For instance, for ethyl esters the equilibrium for ethyl decanoate and ethyl oleate was achieved after $2 \mathrm{~h}$, and with smaller chain length of ethyl esters, the maximum of conversion was at $1 \mathrm{~h}$. The reaction equilibrium for hexyl octanoate was reached after $2 \mathrm{~h}$, and for hexyl decanoate and hexyl oleate after $8 \mathrm{~h}$ of reaction. However it is possible that low conversions for shorter chain ethyl esters can be attributed to the instability of the respective miniemulsion system. Phase separation and destabilization of the miniemulsion during the synthesis of hexyl heptanoate was observed leading to the low conversion yield termination of the reaction after $1 \mathrm{~h}$.

The profile of conversion yields at the equilibrium was very similar for ethyl and hexyl esters but the latter generally shows higher conversion yields in compared to ethyl esters (Fig. 4). The maximum conversion yields were found for decanoic acid $\left(\mathrm{C}_{10}\right)$ for both ethyl (59\%) and hexyl (76\%) esters. The conversion yields for ethyl heptanoate $\left(\mathrm{C}_{7}\right)$ and octanoate $\left(\mathrm{C}_{8}\right)$ were very low $1 \%$ and $5 \%$, respectively and the synthesis of ethyl hexanoate $\left(\mathrm{C}_{6}\right)$ was not detectable. Conversely, for oleic acid (unsaturated $\mathrm{C}_{18}$ ), the conversion at equilibrium was $40 \%$ (Fig. 4). Regarding 
hexyl esters, shorter chain acids also gave lower conversion yield not detectable for hexyl hexanoate, and of 10,52 and $76 \%$ for heptanoate, octanoate and decanoate, respectively. Also the esterification of hexanol with oleic acid $\left(\mathrm{C}_{18}\right)$ by cutinase gives an unexpectedly high conversion yield at equilibrium of 69\% (Fig. $4)$.

These results confirm the observations by Manabe et al. [29] of chemical synthesis dehydrative esterification, that hydrophobic and lipophobic substrates favor esterification reactions in miniemulsion systems, probably due to the formation of very stable hydrophobic droplets. Additionally, due to their nanosize that allow a huge reaction surface and the water, which is formed by esterification inside of the droplets, is directly expelled out of the hydrophobic droplets even in presence of a large amount of water used as continuous phase [29]. Thus, compared to completely water soluble reactants as acids of short chain length, the equilibrium of the reaction with longer and high lypophilic acids is displaced in favor of ester formation.

Cutinase used in a similar type of miniemulsion system shows potential not only for hydrophobic substrates (carboxylic acids, $\mathrm{C}_{10}$ and $\mathrm{C}_{18}$ ) but also for enzymatic synthesis of hydrophilic (ethanol) substrates, and partly hydrophilic substrates (hexanol, carboxylic acids from $\mathrm{C}_{6}$ to $\mathrm{C}_{8}$ ). In more detailed studies it will be necessary to optimize the miniemulsion composition especially the amount of hydrophobic agent and surfactant.

The low conversion yield and the low initial conversion rate for ethyl esters may be the result of the high solubility of ethanol in the continuous phase water and a 
strong inhibition effect of ethanol on cutinase activity. This is due to the fact that ethanol is more polar than hexanol, and its concentration in the aqueous phase is high. This could induce stripping of essential water from the enzyme environment, resulting in an inhibition effect.

\subsubsection{Esterification in iso-octane}

Iso-octane as an adequate esterification reaction medium for ethyl ester formation from different carboxylic acids with different chain lengths as acetic $\left(\mathrm{C}_{2}\right)$, butyric $\left(\mathrm{C}_{4}\right)$, pentanoic $\left(\mathrm{C}_{5}\right)$, hexanoic $\left(\mathrm{C}_{6}\right)$, octanoic $\left(\mathrm{C}_{8}\right)$, decanoic $\left(\mathrm{C}_{10}\right)$ and oleic acid (unsaturated, $\mathrm{C}_{18}$ ) was also investigated. Reactions were performed with equimolar concentration of the substrates $(0.1 \mathrm{M})$ at $30^{\circ} \mathrm{C}$. The higher concentration of substrates showed inhibition effect on cutinase activity in the esterification in iso-octane (data not shown).

A maximal rate of ethyl ester formation $\left(\mathrm{V}, \mu \mathrm{molmg} \mathrm{min}^{-1}\right)$ catalyzed by cutinase was obtained for butyric acid $\left(\mathrm{C}_{4}\right)$ and the minimal values was found for acetic $\left(\mathrm{C}_{2}\right)$ and oleic $\left(\mathrm{C}_{18}\right)$ acid, with the extreme of chain lengths tested in this work. The results are in partial agreement with those reported by Sebastião et al. in Deleted: the reversed micellar system [23] (Fig. 5). The exception is that in reversed micellar systems, cutinase does not present a significant activity on oleic acid. Although, esterification reactions performed by cutinase in iso-octane presents a "lag "phase which is the time that cutinase needs before starting to be detected and quantified, the formation and accumulation of ester in the reaction media (Figure 5) and this 
time increases with the chain length of acids and they were found to be 10,20 and 40 min for octanoic, decanoic and oleic acids, respectively (Figure 5).

The esterification reactions for different chain length of acids at these experimental conditions reaches their equilibria after $8 \mathrm{~h}$ with a maximum value for ethyl pentanoate (95\%) and high yields for almost all the other ethyl esters, such as acetate $(88 \%)$, butyrate $(86 \%)$, hexanoate $(64 \%)$, octanoate $(91 \%)$, decanoate $(82 \%)$ and lowest value for oleate $(43 \%)$. The rates of esterification after $1 \mathrm{~h}$ for ethyl hexanoate and ethyl octanoate were not significantly different (Fig. 5), but the final conversion yield for ethyl hexanoate was slightly lower maybe due to some inhibitory or deactivation effect of hexanoic acid on cutinase activity (Fig. 6). Hexanoic acid inhibitory effect at concentration of $0.1 \mathrm{M}$ and cutinase specificity for short chain acids was observed by Cunnah et al._[32] in CTAB reverse micellar system. Significant drop in conversion yield (Figure 6) between butyric acid and hexanoic acid may be results of cutinase specificity, was shown by previous work too [32] . At this substrate concentration octanoic acid shown less inhibitory effect on cutinase. Still, these results confirm the selectivity of cutinase for shorter chain acids $\left(\mathrm{C}_{4}-\mathrm{C}_{6}\right)$ and iso-octane shows to be an adequate organic solvent to perform enzymatic esterifications.

\section{Concluding remarks:}

The enzymatic esterification of ethyl- and hexyl esters by cutinase in two different reaction media, a miniemulsion system and iso-octane, was demonstrated. 
Cutinase shows a distinct selectivity for short chain ethyl esters in iso-octane confirming the results obtain by previous authors [30-32] as the maximum of cutinase activity was exhibited for ethyl butyrate $\left(\mathrm{C}_{4}\right)$ and pentanoate $\left(\mathrm{C}_{5}\right)$. Enzymatic synthesis in an organic solvent (iso-octane) still favors the synthesis of short chain alkyl esters and good esterification yields were obtained (ethyl butanoate $86 \%$, ethyl pentanoate $95 \%$ ).

Miniemulsion systems also showed to have a great potential as a reaction media for synthesis of ethyl- and hexyl esters catalyzed by cutinase. The cutinase was more tolerant for high substrate concentration, comparing with the iso-octane as reaction medium. Interestingly the syntheses are characterized by a shift of the enzyme selectivity towards carboxylic acids with longer chain length especially decanoic acid $\left(\mathrm{C}_{10}\right)$ and additionally surprisingly good activity on oleic acid $\left(\mathrm{C}_{18}\right)$. It was interesting to verify and prove with this work that cutinase catalyzed esterification reaction occurred in a miniemulsion system and surprisingly led to excellent conversion yields of 59 and $76 \%$ after $8 \mathrm{~h}$ for decanoic acid $\left(\mathrm{C}_{10}\right)$ with ethanol and hexanol, respectively, applied with the 4 to 10 fold concentration substrates than in iso-octane. This is only possible because of the accumulation of substrates in miniemulsion droplets prevents direct contact with the enzyme as when used in iso-octane as reaction media. This prevents the equilibrium to be shifted back to the educts by hydrolysis of the ester.

These results underline that the miniemulsion system has perspective for the synthesis of longer chain alkyl esters $\left(\mathrm{C}_{18}\right)$, and as the reaction occur mainly in water ("clean solvent"), it is a very interesting approach for the application for 


\section{Acknowledgements}

COST Action: COST-STSM-865-02962

Fundação para a Ciência e Tecnologia (F.C.T.) for Ph.D fellowship $\mathrm{SFRH} / \mathrm{BD} / 24703 / 2005$

\section{Conflict of interest statement}

The authors have declared no conflict of interest

\section{References}

[1] Hills, G., Industrial use of lipase to produce fatty acid esters. Eur. J. Lipid Sci. Technol., 2003, 105, 601-607.

[2] Hari-Krishna, S., Karanth, N.G., Lipases and lipase-catalyzed esterification in non-aqueous media, Catalysis reviews , 2002, 44,499-591.

[3] Berger, R.G., Aroma Biotechnology, $1^{\text {st }}$ edn. Springer, Heidelberg, 1995.

[4] Turner, N.J., Recent Advances in the use of enzyme-catalysed reactions in organic synthesis, Natural prod. Reports. 1989, 625-644. 
[5] Serra, S., Fuganti, C., Brenna, E., Biocatalytic preparation of natural flavours and fragrances, Trends in Biotechn. 2005, 23, 193-198.

[6] Schrader, J., Etschmann, M.M.W., Sell, D., Hilmer, J.-M., et al., Applied biocatalysis for the synthesis of natural flavour compounds-current industrial processes and future prospects, Biotechnology Letters.2004, 26, 463-472.

[7] Gandhi, N.N.x.Patil, N.S., Sawant, S.B., Joshi, J.B., et al., Lipase-catalyzed esterification ${ }_{k}$ Cat. Reviews.2000, 42, 439-480.

Deleted:

Deleted:

[8] Cabral, J.M.S., Aires-Barros, M.R., Biocatalysis in Organic media by cutinase in Reversed micelles and zeolites, Chimia. 1996, 50, 420-421.

[9] Vija, H.,Telling, A., Tougu V., Lipaze-catalyzed esterification in supercritical carbon dioxide and in hexane. Bioorg. Med. Chem. Lett. 1997, 7, 259-262.

[10] Lozano, P., Diogo, T.D., Carrié, D., Vaultier, M. et al., Enzymatic esters synthesis in ionic liquids. Journal of Molecular Catalysis B: Enzymatic, 2003, 21, 9-13.

[11] Janssen, A.E.M., Lefferts, A.G., Van’t Riet, K., Enzymatic synthesis of. carbohydrate esters in aqueous media. Biotechnol Lett. 1990, 12, 711-716. 
[12] Ross, N.W., Schneider, H., Activities of Candida rugosa lipase and other esterolytic enzymes coated on glass beads and suspended in substrate and water vapor enzymes in thin liquid films. Enzyme Microb Technol. 1991, 13, 370-377.

[13] Vermuë, M.H., Tamper, J., Biocatalysis in non-conventional media: medium engineering aspects. Pure \& Appl. Chem. 1995, 67, 345-373.

[14] Cernia, E., Palocci, C., Soro, S., The role of the reaction medium in lipase catalyzed esterification and transesterification. Chem. and Physic of Lipids.1998, 93, 157-168.

[15] Cantone, S., Hanefeld, U., Basso, A., Biocatalysis in non-conventional media-ionic liquids, supercritical fluids and gas phase. Green Chem.2007, 9, 954971.

[16] Moniruzzaman, M., Kamiya, N., Nakashima, K., Goto, M., Water-in-ionic liquid microemulsions as a new medium for enzymatic reactions. Green Chem. $2008,10,497-500$.

[17] Gubicza, L., Szakács-Schmidt, A.,On-line water removal during enzymatic asymmetric esterification in organic media. Biotechnology Techniques.1995, 9, 687-690. 
[18] Deng, L., Tan, T., Wang, F., Xu, X., Enzymatic production of fatty acid alkyl esters with a lipase preparation from Candida sp. 99-125. Eur. J. Lipid Sci. Technol. 2003, 105, 727 -324.

[19] Ran, N., Zhao, L., Chen, Z., Tao, J., Recent application of biocatalysis in developing green chemistry for chemical synthesis at the industrial scale. Green Chem. 2008, 10, 361-372.

[20] Wei, W., Keh, C. C. K., Li, C.-J., Water as reaction medium for clean chemical processes. Clean Techn. Environ. Policy. 2005, 7, 62-69.

[21] Landfester, K., Synthesis of colloidal particles in miniemulsions. Annu. Rev. Mater. Res. 2006, 36, 231-279.

[22] Landfester, K., Polyreactions in miniemulsions. Adv. Mater. 2001, 13, 765768.

[23] Calado, C. R. C., Almeida, C., Cabral, J. M. S., Fonseca, L. P. . Development Deleted: of a Fed-Batch Cultivation strategy for the Enhanced Production and secretion of Cutinase by a Recombinant Saccharomyces cerevisiae SU50 Strain. Journal of Bioscience and Bioengineering. 2003, 96, 141-148. 
[24] Calado, C. R. C., Cabral, J. M. S., Fonseca, L. P., Effect of Saccharomyces cerevisiae fermentation conditions on expanded bed adsorption of heterologous cutinase. J. Chem. Technol. Biotechnol. 2002, 77, 1231 -1237.

[25] Instruction from the manual, producer PIERCE.

[26] Almeida, C. F., Cabral, J. M. S., Fonseca, L. P. Flow injection analysis system for on-line cutinase activity assay. Analytica Chimica Acta. 2004, 502, $115-124$.

[27] Sambrook, J. Fritsch, E. F., Maniatis, T. Molecular cloning, a laboratory manual, 2nd edition. Cold Sp. Har Lab. Pres. 3, 1989, pp 1847-1866.

[28] Aschenbrenner, E. M., Weiss, C. K., Landfester, K., Enzymatic esterification in aqueous miniemulsion.Chemistry-A European Journal, 2009, in print.

[29] Manabe, K., Iimura, S., Sun, X.-M., Kobayashi, S., Dehydration reaction in water. Brønsted acid-surfactant-combined catalyst for ester, ether, thioehter, and dithioacetal formation in water. J. Am. Chem. Soc. 2002, 124, 11971-11978.

[30] Pinto-Sousa, A. M. ${ }_{x}$ Cabral, J. M. S. Aires-Barros, M. R. Ester synthesis by a recombinant cutinase in reversed micelles of a natural phospholipid. Biocatalysis. 1994, 9, 169-179. 
[31] Sebastião, M. J., Cabral, J. M. S., Aires-Barros, M. R. . Synthesis of fatty acid esters by a recombinant cutinase in reversed micelles. In: Tramper J,Vermue MH, Beeftink JH, von Stockar U, editors. Biocatalysis in non-conventional media. Amsterdam: Elsevier. 1992, 719-724.

[32] Cunnah, P. J., Aires-Barros, M. R., Cabral, J. M. S., Esterification and transesterification catalysed by cutinase in reverse micelles of CTAB for the synthesis of short chain esters, Biocatalysis and Biotransformation. 1996, 14, 125 146.

[33] ICSC-1048, Prepared in the context of cooperation between the International Programme on Chemical Safety and the Commission of the European Communities (C IPCS, CEC ,1999 
Figure Captions

Fig.1. Principle of esterification in a miniemulsion system.

Fig.2. ${ }^{1} \mathrm{H}$ NMR spectrum for synthesis of ethyl decanoate

Fig. 3. Rate of synthesis after $1 \mathrm{~h}$ of ethyl- and hexyl esters for carboxylic acids from $\mathrm{C}_{6}$ to $\mathrm{C}_{18}$ in miniemulsion system. Reaction condition are shown in Table 1.

Fig. 4. Conversion yields at equilibrium (8h) for the synthesis of ethyl- and hexyl esters for carboxylic acids from $\mathrm{C}_{6}$ to $\mathrm{C}_{18}$ in miniemulsion system.

Fig. 5. The influence of the acid chain length on the synthesis parameters $\mathrm{v}$ and lag time of ethyl esters by cutinase in iso-octane.

Fig 6. Conversion yields (8h) for the synthesis of ethyl esters by cutinase in isooctane. 
Table 1. Equimolar concentration of substrates in miniemulsion system for the synthesis of ethyl- and hexyl esters

\begin{tabular}{lll}
\hline Acids & $\begin{array}{l}\text { For ethyl esters } \\
(\mathrm{M})\end{array}$ & $\begin{array}{l}\text { For hexyl esters } \\
(\mathrm{M})\end{array}$ \\
\hline Hexanoic & 1,0 & 0.75 \\
Heptanoic & 0.9 & 0.70 \\
Octanoic & 0.8 & 0.65 \\
Decanoic & 0.7 & 0.6 \\
Oleic & 0.5 & 0.4 \\
\hline
\end{tabular}


Table 2. The composition of the miniemulsion systems with

$80 \%$ of amount of water as esterification reaction medium.

Ingredients $\%(\mathrm{w} / \mathrm{w})$

\begin{tabular}{ll}
\hline Substrates & 16.56 \\
Hexadecane & 0.66 \\
$\mathrm{H}_{2} \mathrm{O}$ & 81.16 \\
Lutensol & 1.62 \\
\hline $\mathbf{\Sigma}$ & 100
\end{tabular}


Table 3. Solubility of carboxylic acids in water at $20^{\circ} \mathrm{C}$. [33]

\begin{tabular}{ll}
\hline Acids & Solubility, g/100ml \\
\hline Hexanoic acid & 1.1 \\
Heptanoic acid & 0.24 \\
Octanoic acid & 0.068 \\
Decanoic acid & very low \\
Oleic acid & very low \\
\hline
\end{tabular}




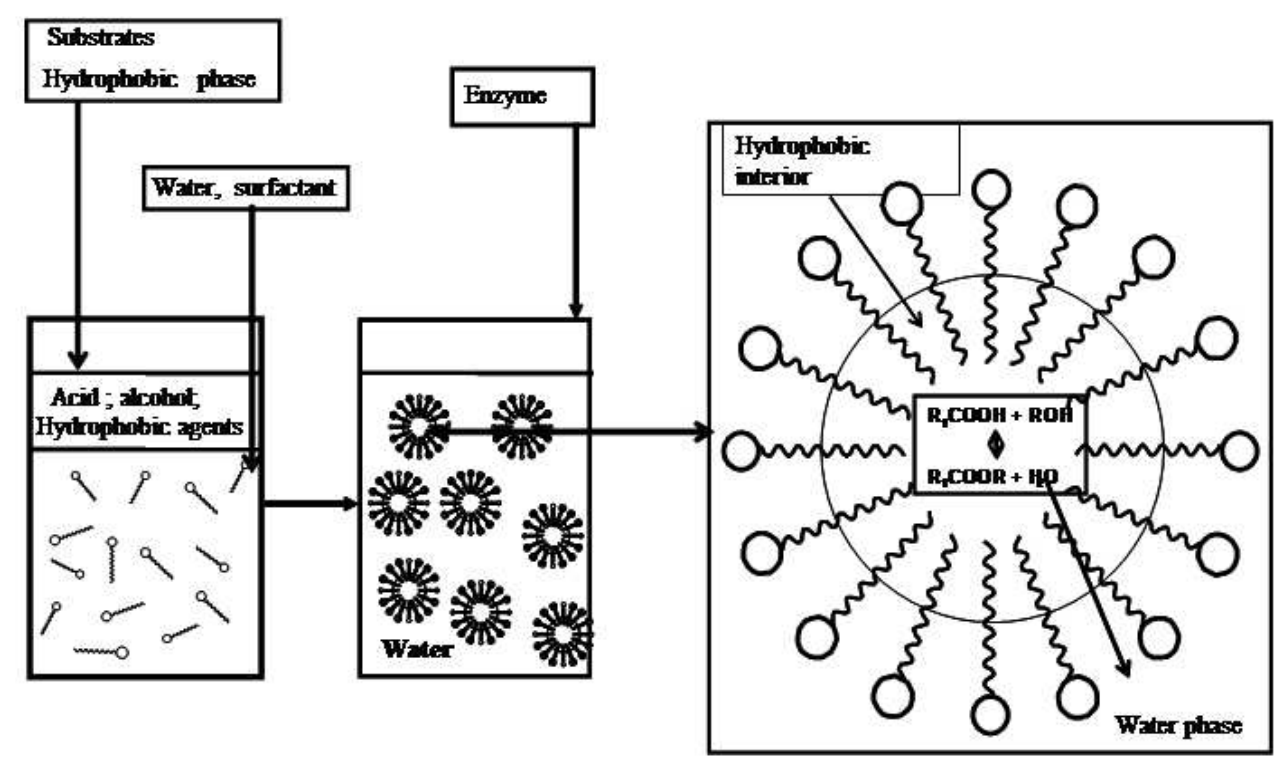

Fing 1.

Banos etal 


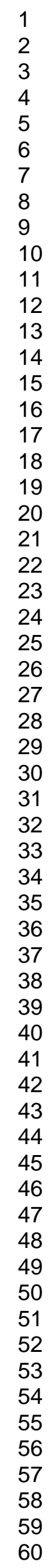

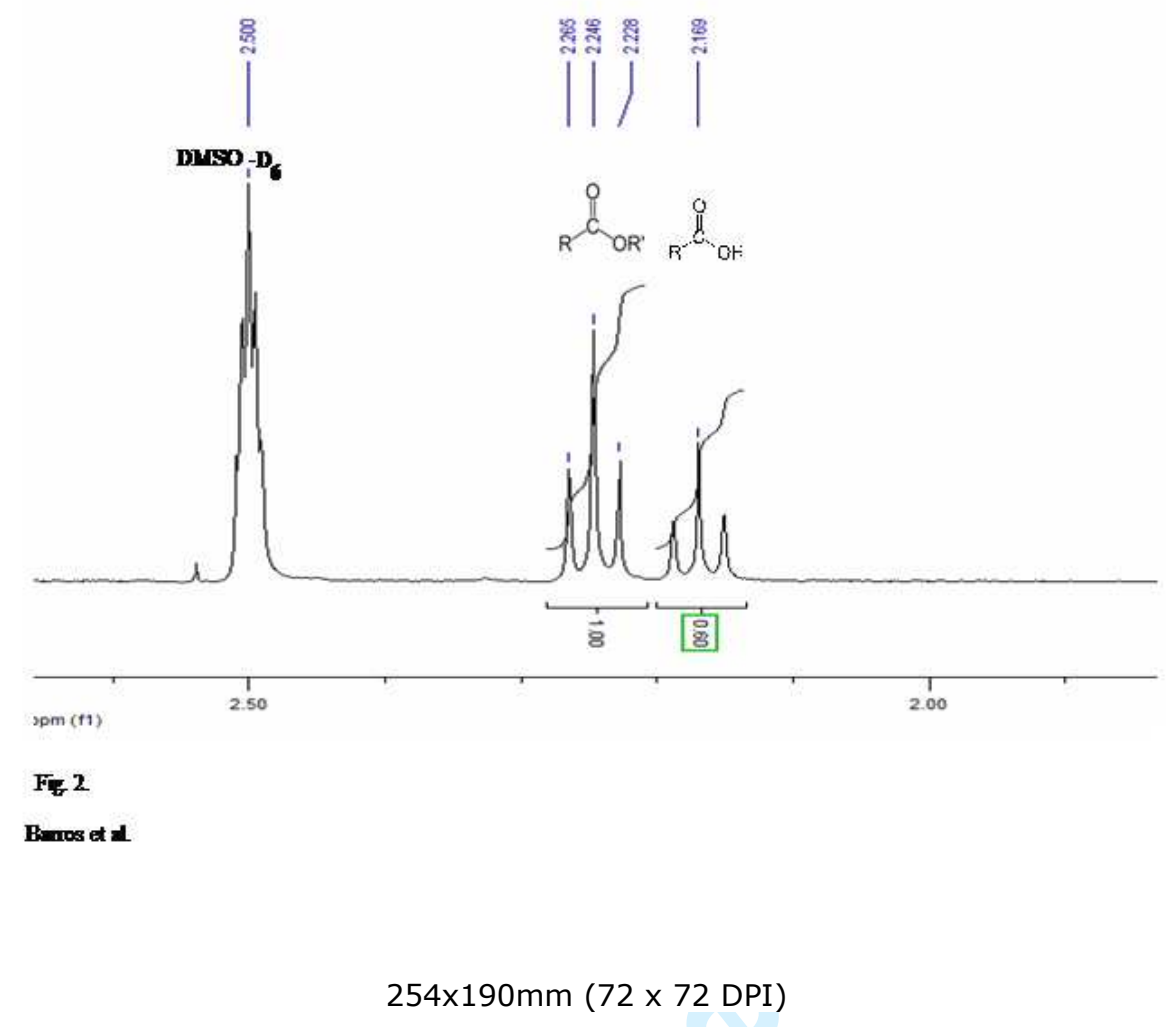




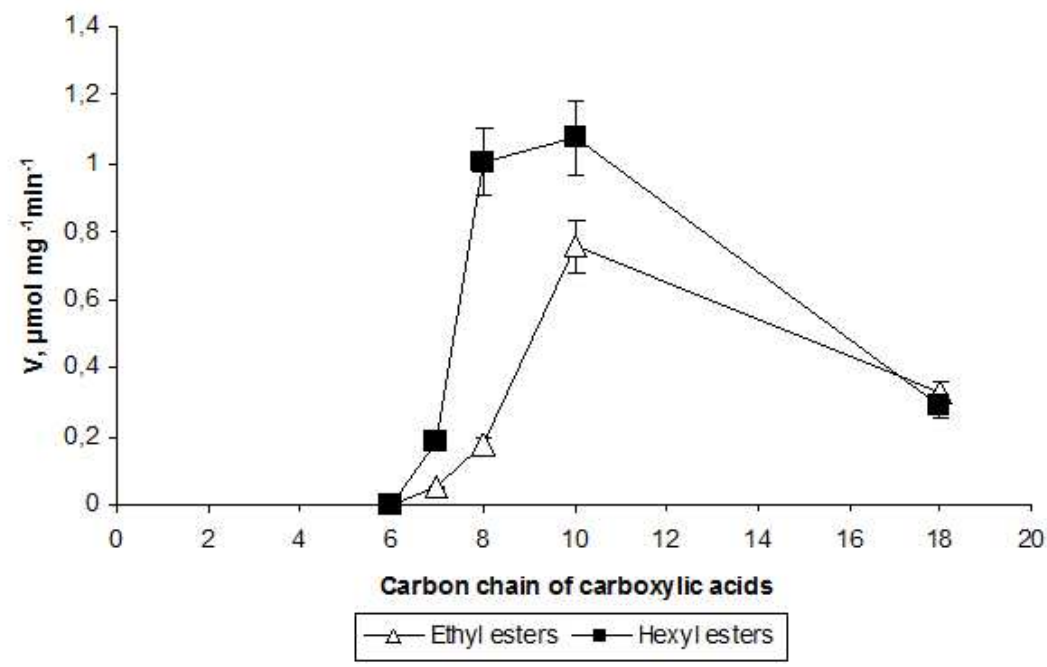

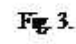

Bmos et al

$254 \times 190 \mathrm{~mm}(72 \times 72 \mathrm{DPI})$ 


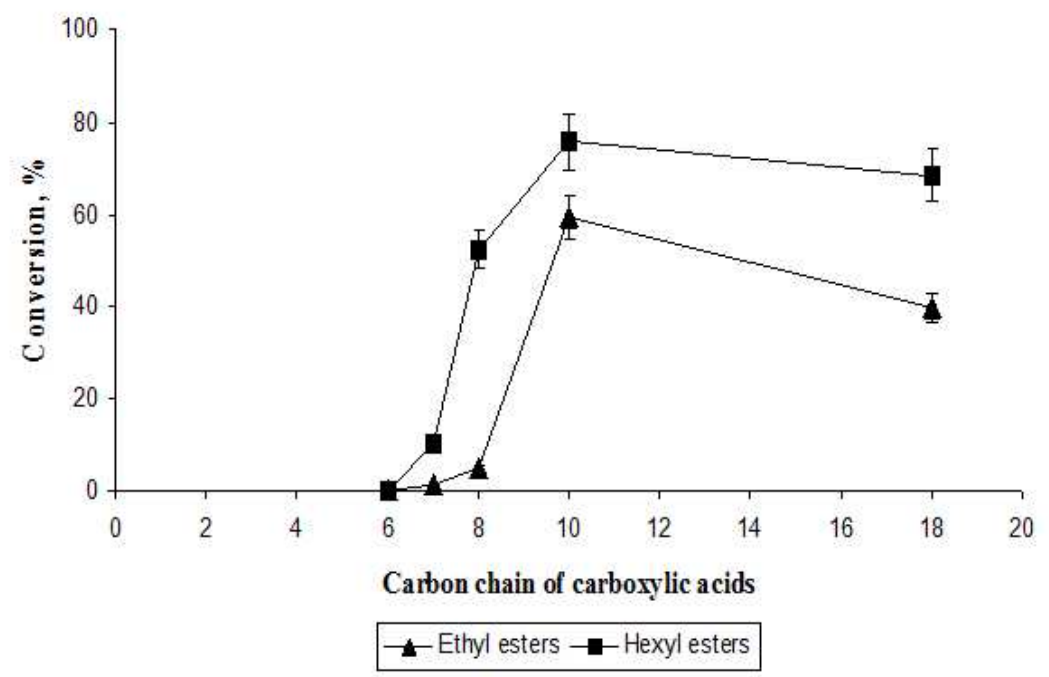

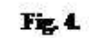

Barros ef al

$254 \times 190 \mathrm{~mm}(72 \times 72$ DPI $)$ 


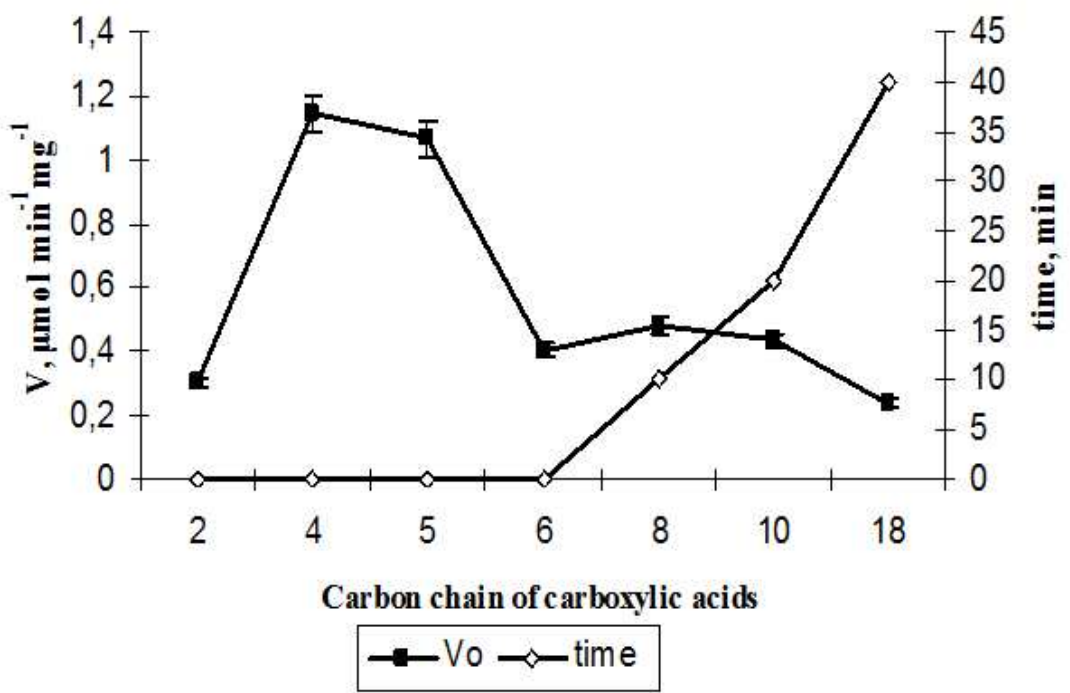

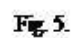

Binos et al

$254 \times 190 \mathrm{~mm}(72 \times 72$ DPI $)$ 
Fig 6. Conversion yields for the synthesis of ethyl esters by cutinase in iso-octane. $254 \times 190 \mathrm{~mm}(72 \times 72 \mathrm{DPI})$ 